\title{
Basic problems of the metric fixed point theory and the relevance of a metric fixed point theorem
}

\author{
IOAN A. RUS and MARCEL-ADRIAN ŞERBAN
}

\begin{abstract}
.
In this paper we present some basic problems of the metric fixed point theory (existence, uniqueness, settheoretic aspects (Bessaga, Janos, Rus, ...), order-theoretic aspects (Ekeland, Bronsted, Caristi, Kirk, Jachymski, ...), convergence of the succesive approximations, data dependence (general estimation, Ulam problem, dependence on the parameters, ...), well-posedness of the fixed point problem, limit shadowing property, stability, Gronwall lemmas, comparison lemmas, retractibility, ...). Following [I. A. Rus, The theory of a metrical fixed point theorem: theoretical and applicative relevances, Fixed Point Theory, 9 (2008), No. 2, 541-559] we define the relevance of a metrical fixed point theorem by the impact of the theorem on these basic problems. Some case studies are presented.
\end{abstract}

Acknowledgment. This work was supported by a grant of the Romanian National Authority for Scientific Research, CNCS - UEFISCDI, project number PN-II-ID-PCE-2011-3-0094.

\section{REFERENCES}

[1] Agarwal, R. P., El-Gebely, M. A. and O'Regan, D., Generalized contractions in partially ordered metric spaces, Appl. Anal., 87 (2008), No. 1, 109-116

[2] Agarwal, R. P., Meehan, M. and O'Regan, D., Fixed Point Theory and Applications, Cambridge, Univ. Press, 2001

[3] Aldea, F., Degenerating metrical conditions, Bull. Math. Soc. Sc. Math. Roumanie, 45 (2002), No. 1-2, 3-8

[4] Angelov, V. G., Fixed point theorem in uniform spaces and applications, Czech. Math. J., 37 (1987), 19-33

[5] Angelov, V. G., A converse to a contraction mapping theorem in uniform spaces, Nonlinear Analysis, 12 (1988), No. 10, 989-996

[6] Bellen, A. and Valčič, A., Non-cyclic transformations and uniform convergence of the Picard sequences, Rend. Ist. di Matem. Univ. Trieste, 4 (1972), fas. 1, 1-7

[7] Berinde, V., Generalized Contractions and Applications, Cub Press, Baia Mare, 1997 (in Romanian)

[8] Berinde, V., Iterative Approximation of Fixed Points, Springer, Berlin, 2007

[9] Berinde, V., Stability of Picard iteration for contractive mappings satisfying an implicit relation, Carpathian J. Math., 27 (2011), No. 1, 13-23

[10] Bernfeld, S. and Lakshmikantham, V., An Introduction to Nonlinear Boundary Value Problems, Acad. Press, New York, 1974

[11] Bessaga, C., On the converse of the Banach fixed point principle, Colloq. Math., 7 (1959), 41-43

[12] Bonsal, F. F., Lectures on Some Fixed Point Theorems of Functional Analysis, Tata Inst. Fund. Res., Bombay, 1962

[13] Browder, F. E., On a theorem of Caristi and Kirk, Fixed Point Theory and its Applications (S. Swaminathan, ed.), Acad. Press, New York, 1976, 23-27

[14] Brown, R. F., Retraction mapping principle in Nielsen fixed point theory, Pacific J. Math., 115 (1984), 277-297

[15] Buică, A., Coincidence Principles and Applications, Presa Univ. Clujeană, Cluj-Napoca, 2001 (in Romanian)

[16] Burton, T. A., Stability by fixed point methods for highly nonlinear delay equations, Fixed Point Theory, 5 (2004), No. $1,3-20$

Received: 30.01.2013; In revised form: 27.05.2013; Accepted: 04.06.2013

2010 Mathematics Subject Classification. 47H10, 54H25, 47H09, 47J25, 34A40, 34D20, 35B35, 45Gxx, 37C75.

Key words and phrases. Metric space, generalized metric space, generalized contraction, fixed point, Bessaga operator, Janos operator, data dependence, Picard operator, weakly Picard operator, well-posedness, limit shadowing property, stability, Gronwall lemmas, comparison lemmas, retractibility.

Corresponding author: M. A. Şerban; mserban@math.ubbcluj.ro 
[17] Burton, T. A., Stability by Fixed Point Theory for Functional Differential Equations, Dover Publications, New York, 2006

[18] Carbone, A., On some fixed point theorems, Jñãnãbha, 18 (1988), 27-29

[19] Caristi, J., Fixed points theorems for mappings satisfying inwardness conditions, Trans. Amer. Math. Soc., 215 (1976), 241-251

[20] Chang, S. -S. and Zhong, Q.-C., On Rhoades' open questions, Proc. Amer. Math. Soc., 109 (1990), 269-274

[21] Chen, Y.-Z., Inhomogeneous iterates of contraction mappings and nonlinear ergodic theorems, Nonlinear Anal., 39 (2000), $1-10$

[22] Chidume, C., Geometric Properties of Banach Spaces and Nonlinear Iterations, Springer, 2009

[23] Chidume, C. and Măruşter, Şt., Iterative methods for computation of fixed points of demicontractive mappings, J. Comput. Appl. Math., 234 (2010), 861-882

[24] Chiş-Novac, A., Precup, R. and Rus, I. A., Data dependence of fixed points for non-self generalized contractions, Fixed Point Theory, 10 (2009), No. 1, 73-87

[25] Collaço, P. and Silva, J. C. E., A complete comparison of 25 contraction conditions, Nonlinear Analysis, 30 (1997), $471-476$

[26] Colojoară, I., Sur un théorème de point fixe dans les espaces uniformes complets, Com. Acad. R. P. Română, 11 (1961), 281-283

[27] Cooke, R. G., Infinite Matrices and Sequence Spaces, London, 1950

[28] Corduneanu, C., Abstract Volterra equations: a survey. Nonlinear operator theory, Math. Comput. Modelling, 32 (2000), 1503-1528

[29] D'Apuzzo, L., On the notion of good and special convergence of the method of successive approximations, Ann. Istit. Univ. Navale Napoli, 45/46 (1976/1977), 123-138

[30] De Blasi, F. S. and Myjak, J., Sur la porosité de l'ensemble des contractions sans point fixe, C. R. Acad. Sci. Paris, 308 (1989), 51-54

[31] Dancs, S., Hegedüs, M. and Medvegyev, P., A general ordering and fixed point principle in complete metric space, Acta Sci. Math., 46 (1983), 381-388

[32] Deimling, K., Nonlinear Functional Analysis, Springer, Berlin, 1985

[33] Delbosco, D., Un'estensione di un teorema sul punti fisso di S. Reich, Rend. Sem. Mat. Univ. Politech. Torino, 35 (1976-77), 233-238

[34] De Pascale, E., Marino, G. and Pietramala, P., The use of the E-metric spaces in the search of fixed points, Le Matematiche, 48 (1993), fas. II, 367-376

[35] Dieudonné, J., Sur la convergence des approximations succesive, Bull. Sci. Math., 69 (1945), 62-72

[36] Dugundji, J., Positive definite functions and coincidence, Fund. Math., 90 (1976), 131-142

[37] Dugundji, J. and Granas, A., Weakly contractive maps and elementary domain invariance theorems, Bull. Greek Math. Soc., 19 (1978), 141-151

[38] Eirola, T., Nevalina, O. and Pilyugin, S. Yu., Limit shadowing property, Num. Funct. Anal. Optm., 18(1997), $75-92$

[39] Frigon, M., Fixed point and continuation results for contractions in metric and gauge spaces, Banach Center Publications, 77 (2007), 89-114

[40] Gheorghiu, N., Fixed point theorems in uniform spaces, An. Şt. "Al. I. Cuza" Univ., Mat., 28 (1982), 17-18

[41] Glăvan, V. and Guţu, V., Attractors and fixed points of weakly contracting relations, Fixed Point Theory, 5 (2004), No. 2, 265-284

[42] Glăvan, V. and Guţu, V., Shadowing in parametrized IFS, Fixed Point Theory, 7 (2006), No. 2, 263-274

[43] Goebel, K. and Kirk, W. A., Topics in Metric Fixed Point Theory, Cambridge Univ. Press, London, 1990

[44] Gohberg, I., Goldberg, S. and Kaashoek, M. A., Basic Classes of Linear Operators, Birkhäuser, Basel, 2003

[45] Granas, A. and Dugundji, J., Fixed Point Theory, Springer, Berlin, 2003

[46] Guseman, L. F., Fixed point theorems for mappings with a contractive iterate at a point, Proc. Amer. Math. Soc., 26 (1970), No. 4, 615-618

[47] Heikkilä, S. and Seikkala, S., On fixed points in uniform spaces with applications to probabilistic metric spaces, Acta Univ. Oulu. Ser. A Sci. Rerum Natur. Math., No. 18

[48] Hirsch, M.W. and Pugh, C. C., Stable manifolds and hyperbolic sets, Proc. Symp. in Pure Math. AMS, 14 (1970), $133-143$

[49] Ivanov, A. A., Fixed Points of Metric Space Mappings, LOMI, Leningrad, 1976 (in Russian)

[50] Jachymski, J., An extension of A. Ostrovski's theorem on the round-off stability of iterations, Aeq. Math., 53 (1997), 242-253

[51] Jachymski, J., Converses to fixed point theorems of Zermelo and Caristi, Nonlinear Anal., 52 (2003), 1455-1463

[52] Jachymski, J., Equivalent conditions for generalized contractions on (ordered) metric spaces, Nonlinear Anal., 74 (2011), 768-774 
[53] Jachymski, J., The contraction principle for mappings on a metric space with graph, Proc. Amer. Math. Soc., 136 (2008), 1359-1373

[54] Jachymski, J. and Jóźwik, I., Nonlinear contractive conditions: a comparison and related problems, Banach Center Publications, 77 (2007), 123-146

[55] Janos, L,. A converse of Banach's contraction theorem, Proc. Amer. Math. Soc., 68 (1978), 121-124

[56] Khamsi, M. A. and Kirk, W. A.. An Introduction to Metric Spaces and Fixed Point Theory, Wiley, New York, 2001

[57] Kirk, W. A., Contraction mappings and extensions, 1-34, in [?]

[58] Kirk, W. A., Metric fixed point theory: old problems and newdirections, Fixed Point Theory, 11 (2010), No. 1, $45-58$

[59] Kirk, W. A. and Sims, B.(eds.), Handbook of Metric Fixed Point Theory, Kluwer, 2001

[60] Krasnoselskii, M. A. and Zabrejko, P. P., Geometrical Methods in Nonlinear Analysis, Springer, Berlin, 1984

[61] Lakshmikantham, V. and Leela, S., Differential and Integral Inequalities, Acad. Press, New York, 1969

[62] Lalescu, T., An example of successive approximations, Gazeta Matematică (Bucureşti), 13 (1908), 97-102 (in Romanian)

[63] Liu, Z. and Park, K. P., On two classes of mappings with nonunique fixed points, Nonlinear Funct. Anal. Appl., 6 (2001), No. 2, 307-311

[64] Liu, Y. and Li, Z., Schaefer type theorem and periodic solution of evolution, J. Math. Anal. Appl., 316 (2006), 237-255

[65] de Malafosse, B. and Malkowsky, Sequences spaces and inverse of an infinite matrix, Rend. Circ. Mat. Palermo, 51 (2002), 277-294

[66] Matkowski, J., Integrable solutions of functional equations, Dissertationes Math., 127 (1975)

[67] Matouskova, E., Reich, S. and Zaslavski, A. J., Genericity in nonexpansive mapping theory, Advanced Courses of Mathematical Analysis I, World Scientific, 2004, 81-98

[68] Matthews, S. G., Partial metric spaces, Univ. Warwick, Depart. of Computer Science, Research Report No. 212,1992

[69] Matthews, S. G., Partial metric topology, Ann. New York Acad. Sci., 728 (1994), 183-197

[70] Meyers, P. R., A converse to Banach's contraction theorem, J. Research Nat. Bureau of Standards, B. Math. Physics, 71B (1967), 73-76

[71] Mureşan, V., Functional-Integral Equations, Mediamira, Cluj-Napoca, 2003

[72] Nadler, S. B., Sequence of contractions and fixed points, Pacific J. Math., 27 (1968), 579-585

[73] Niemytzki, V., The method of fixed points in analysis, Uspekhi Mat. Nauk, 1 (1936), 141-174 (in Russian)

[74] Olatinwo, M. O., Some results on the continuous dependence of the fixed points in the normed linear spaces, Fixed Point Theory, 10 (2009), No. 1, 151-157

[75] Oltra, S. and Valero, O., Banach's fixed point theorem for partial metric spaces, Rend. instit. Mat. Univ. Trieste, 36 (2004), 17-26

[76] Opoitsev, V. I., A converse to the principle of contracting maps, Uspekhi Mat. Nauk, 31 (1976), 169-198 (in Russian)

[77] O'Regan, D. and Precup, R., Theorems of Leray-Schauder Type and Applications, Gordon and Breach Sc. Publ., Amsterdam, 2001

[78] Ostrowski, A. M., The round off stability of iterations, Z. Angew. Math. Mech., 47 (1967), 77-81

[79] Otrocol, D. and Rus, I. A., Functional-differential equation with "maxima", of mixed type, Fixed Point Theory, 9 (2008), 207-220

[80] Păcurar, M., Fixed point theory for cyclic Berinde operators, Fixed Point Theory, 12 (2011), No. 2, 419-428

[81] Păcurar, M. and Rus, I. A., Fixed point theory for cyclic $\varphi$-contractions, Nonlinear Analysis, 72 (2010), 1181-1187

[82] Petruşel, A. and Rus, I. A., Fixed point theorems in ordered L-spaces, Proc. Amer. Math. Soc., 134 (2006), 411418

[83] Petruşel, A., Rus, I. A. and Şerban, M. A., Basic problems of the metric fixed point theory and the relevance of a metric fixed point theorem for a multivalued operator, (to appear)

[84] Petruşel, A., Rus, I. A. and Ş erban, M. A., Equivalent metrics in fixed point theory, (to appear)

[85] Petruşel, A., Rus, I. A. and Şerban, M. A., Fixed points for operators on generalized metric spaces, CUBO a Math. J., 10 (2008), No. 4, 45-66

[86] Piljugin, S. Ju., Shadowing in Dynamical Systems, Springer, 1999

[87] Precup, R.,Le théorème des contractions dans des espaces syntopogènes, Rev. Anal. Numér. Théor. Approx., 9 (1980), 113-123

[88] Proinov, P. D., A generalization of the Banach contraction principle with high order of convergence of succesive approximation, Nonlinear Anal., 67 (2007), 2361-2369 
[89] Radu, V., Ideas and methods in fixed point theory for probabilistic contractions, Seminar on Fixed Point Theory Cluj-Napoca, 3 (2002), 73-98

[90] Radu, V., The fixed point alternative and the stability of functional equations, Fixed Point Theory, 4 (2003), No. 1, 91-96

[91] Reem, D., Reich, S. and Zaslavski, A. J., Two results in metric fixed point theory, J. Fixed Point Theory and Applications, 1 (2007), 149-157

[92] Reich, S. and Zaslavski, A. J., A stability results in fixed point theory, Fixed Point Theory, 6 (2005), No. 1, 113-118

[93] Reich, S. and Zaslavski, A. J., Well-posedness of fixed point problems, Far East J. Math. Sci., Special Volume, Part III, 2001, 393-401

[94] Reich, S. and Zaslavki, A. J., A fixed point theorem for Matkowski contractions, Fixed Point Theory, 8 (2007), No. 2, 303-307

[95] Rezapour, Sh., Haghi, R. H. and Rhoades, B. E., Some results about T-stability, Fixed Point Theory, 12 (2011), No. 1, 179-186

[96] Rhoades, B. E., A comparison of various definitions of contractive mappings, Trans. Amer. Math. Soc., 226 (1970), $257-290$

[97] Rhoades, B. E., Some maps for which periodic and fixed points coincide, Fixed Point Theory, 4 (2003), No. 2, $173-176$

[98] Rus, I. A., A fiber generalized contractions theorem and applications, Mathematica, 41 (1999), No. 1, 85-90

[99] Rus, I. A., An abstract point of view on iterative approximation of fixed points: impact on the theory of fixed point equations, Fixed Point Theory, 13 (2012), No. 1, 179-192

[100] Rus, I. A., Basic problems of the metric fixed point theory revisited (I), Studia Univ. Babeş-Bolyai, Math., 34 (1989), No. 2, 61-69

[101] Rus, I. A., Fiber Picard operators theorem and applications, Studia Univ. Babeş-Bolyai, Math., 44 (1999), No. 3, $89-97$

[102] Rus, I. A., Five open problems in the fixed point theory in terms of fixed point structures (I): singled valued operators, (to appear)

[103] Rus, I. A., Fixed Point Structure Theory, Cluj University Press, 2006

[104] Rus, I. A., Fixed point theory in partial metric spaces, Analele Univ. de Vest, Timişoara, Mat.-Informatică, 46 (2008), No. 2, 149-160

[105] Rus, I. A., Fixed points, upper and lower fixed points: abstract Gronwall , Carpathian J. Math., 20 (2004), No. 1, 125-134

[106] Rus, I. A., Functional-differential equations of mixed type, via weakly Picard operators, Seminar on Fixed Point Theory Cluj-Napoca, 3 (2002), 335-346

[107] Rus, I. A. Generalized Contractions and Applications, Cluj University Press, Cluj-Napoca, 2001

[108] Rus, I. A. Gronwall lemmas: ten open problems, Scientiae Mathematicae Japonicae, 70 (2009), No. 2, 221-228

[109] Rus, I. A., Metrical Fixed Point Theorems, Univ. of Cluj-Napoca, 1979

[110] Rus, I. A., On a theorem of Dieudonné, 296-298, in Diff. Eq. Control Theory (V. Barbu (ed.)), Longmand, 1991

[111] Rus, I. A., Picard operators and applications, Scientiae Mathematicae Japonicae, 58 (2003), No. 1, 191-219

[112] Rus, I. A., Picard operators and well-posedness of fixed point problems, Studia Univ. Babeş-Bolyai Math., 52 (2007), No. 3, 147-156

[113] Rus, I. A., Principles and Applications of Fixed Point Theory, Dacia, Cluj-Napoca, 1979 (in Romanian)

[114] Rus, I. A., Remarks on Ulam stability of the operatorial equations,Fixed Point Theory, 10 (2009), 305-320

[115] Rus, I. A., Results and problems in the metrical common fixed point theory, Mathematica, 21 (1979), 189-194

[116] Rus, I. A., Results and problems in the metrical fixed point theory, Analele Şt. Univ. "Al. I. Cuza" Iaşi, Supliment, 25 (1979), 153-160

[117] Rus, I. A., Results and problems in Ulam stability of operatorial equations and inclusions, (to appear)

[118] Rus, I. A., Sequences of operators and fixed points, Fixed Point Theory, 5 (2004), No. 2, 349-368

[119] Rus, I. A., Some metrical fixed point theorems, Studia Univ. Babeş-Bolyai Math., 24 (1979), No. 1, 73-77

[120] Rus, I. A. Some nonlinear functional and integral equations, via weakly Picard operator theory: a survey, Carpathian J. Math., 26 (2010), No. 2, 230-258

[121] Rus, I. A., theory of a metrical fixed point theorem: theoretical and applicative relevances, Fixed Point Theory, 9 (2008), No. 2, 541-559

[122] Rus, I. A., Ulam stability of the operatorial equations, 287-305, in Functional Equations in Mathematical Analysis (Th. M. Rassias andJ. Brzdęk (eds.)), Springer, 2012

[123] Rus, I. A., Weakly Picard mappings, Comment. Math. Univ. Carolinae, 34 (1993), No. 4, 769-773 
[124] Rus, I. A. and Aldea, F., Fixed points, zeros and surjectivity, Studia Univ. Babeş-Bolyai Math., 45 (2000), No. 4, 109-116

[125] Rus, I. A. and Egri, E., Boundary value problems for iterative functional-differential equations, Studia Univ. Babeş-Bolyai Math., 51 (2006), No. 2, 109-126

[126] Rus, I. A., and Mureşan, S., Data dependence of the fixed points set of weakly Picard operators, Studia Univ. Babeş-Bolyai Math., 43 (1998), No. 1, 79-83

[127] Rus, I. A., Petruşel, A. and Petruşel, G., Fixed Point Theory, Cluj University Press, 2008

[128] Rus, I. A., Petruşel, A. and Petruşel, G., Fixed point theorems for set-valued Y contractions, Banach Center Publications, 77 (2007), 227-237

[129] Rus, I. A., Petruşel, A. and Şerban, M. A., Fibre Picard operators on gauge spaces and applications, J. Anal. Appl., 27 (2008), 407-423

[130] Rus, I. A., Petruşel, A. and Şerban, M. A., Weakly Picard operators: equivalent definitions, applications and open problems, Fixed Point Theory, 7 (2006), No. 1, 3-22

[131] Rus, I. A. and Şerban, M. A., Extensions of a Cauchy lemma and applications, Topics in Mathematics, Computer Science and Philosophy, A Festschrift for Wolfgang W. Breckner, 173-181, Ed. Şt. Cobzaş, University Press, Cluj-Napoca, 2008

[132] Sasu, A. L., Megan, M. and Sasu, B., On Rolewicz-Zabczyk technique in the stability theory of dynamical systems, Fixed Point Theory, 13 (2012), No. 1, 205-236

[133] Schweizer, B., Sherwood, H. and Tardiff, R. M., Contractions on probabilistic metric spaces: examples and counterexamples, Stochastica, 22 (1988), No. 1, 5-17

[134] Şerban, M. A., Fibre contraction theorem in generalized metric spaces, Automation Computers Applied Mathematics, 16 (2007), No. 1-2, 9-14

[135] Şerban, M. A., Fiber $\varphi$-contraction, Studia Univ. Babeş-Bolyai Math., 44 (1999), 99-108

[136] Şerban, M. A., Fixed point theorems for triangular operators, Carpathian J. Math., 24 (2008), No. 3, 409-416

[137] Şerban, M. A., The fixed point theory for the operators on cartesian product, (Romanian), Cluj University Press, Cluj-Napoca, 2002

[138] Smart, D, R., When does $T^{n+1}(x)-T^{n}(x) \rightarrow 0$ imply convergence?, Amer. Math. Monthly, 87 (1980), 748-749

[139] Soardi, P., Su un problema di punto unito di S. Reich, Bull. U. M. I., 4 (1971), 841-845

[140] Szilard, A., Fiber Picard operators and convex cotractions, Fixed Point Theory, 4 (2003), No. 2, 121-129

[141] Takahashi, W., Nonlinear Functional Analysis. Fixed Point Theory and its Applications, Yokohama Publ., 2000

[142] Tarafdar, E., An approach to fixed point theorems on uniform spaces, Trans. Amer. Math. Soc., 191 (1974), 209-225

[143] Ulam, S. M., Problems in modern mathematics, John Wiley, New York, 1964

[144] Zabrejko, P. P., K-metric and K-normed spaces: survey, Collect. Math., 48 (1997), No. 4-6, 825-859

[145] Zabrejko, P. P. and Makarevich, T. A., Generalization of Banach-Caccioppoli principle, Diff. Urav., 23 (1987), 1497-1504

[146] Zeidler, E., Nonlinear Functional Analysis, Vol. I, Fixed Point Theorems, Springer, Berlin, 1993

DEPARTMENT OF MATHEMATICS

BABEŞ-BOLYAI UNIVERSITY OF CLUj-NAPOCA

STR. M. KOGĂLNICEANU 1, 400084, CluJ-NAPOCA, ROMANIA

E-mail address: $\{$ iarus, mserban\}@math.ubbcluj.ro 